\title{
P09- 16. A primary R5 isolate undergoes different escape pathway during in vitro selection with low or high concentration of an anti-V3 monoclonal antibody
}

\author{
C Narahara*, M Hatada, H Shigeyoshi, K Yoshimura and S Matsushita
}

Address: Clinical Retrovirology and Infectious Diseases, Center for AIDS Research, Kumamoto University, Kumamoto, Japan

* Corresponding author

from AIDS Vaccine 2009

Paris, France. 19-22 October 2009

Published: 22 October 2009

Retrovirology 2009, 6(Suppl 3):PI29 doi:10.1 I86/I742-4690-6-S3-PI29

This abstract is available from: http://www.retrovirology.com/content/6/S3/PI29

(c) 2009 Narahara et al; licensee BioMed Central Ltd.

\section{Background}

The mechanisms of immune escape from neutralizing antibody are not fully understood for primary HIV-1 isolates with R5 phenotype. Using two different conditions of the anti-V3 humanized monoclonal antibody (MAb) KD-247 for selecting escape mutants we analyzed the mechanism of escape pathway of a primary $\mathrm{R} 5$ virus.

\section{Methods}

We induced escape variants by exposing a neutralizationsensitive primary R5 isolate, HIV- $1_{\mathrm{MTA}}$ to increasing concentrations of KD-247 in PM1/CCR5 cells. The virus was initially exposed 1 or $0.05 \mu \mathrm{g} / \mathrm{ml}$ of KD-247 and was serially passaged up to $1000 \mu \mathrm{g} / \mathrm{ml}$. We determined the changes in the amino acid (aa) sequences of gp120encoding region at each passage and monitored neutralization sensitivity of the passaged virus by WST- 8 assay. To compare replication fitness of the escape mutants a competition assay was performed in the presence or absence of KD-247.

\section{Results}

Under high KD-247 pressure $(1 \mu \mathrm{g} / \mathrm{ml})$, a substitution of aa in V3 tip (GPGR $\rightarrow$ GQGR, MTA $1313 \mathrm{Q}$ ) was observed at passage $2(\mathrm{p} 2)$ and was subsequently detected in virtually all the clones examined at p5 $(20 \mu \mathrm{g} / \mathrm{ml})$. On the other hand, under relatively low KD-247 pressure $(0.05 \mu \mathrm{g} / \mathrm{ml})$, another substitution in V3 tip (GPGR $\rightarrow$ GPGK, MTA ${ }_{\text {R315K }}$ ) was emerged at p5 $(0.4 \mu \mathrm{g} / \mathrm{ml})$ and was dominated in virtually all subsequent clones at p14 $(10 \mu \mathrm{g} / \mathrm{ml})$. These escape mutants were found to have highly resistant phenotype to KD-247. A series of competition assay of the mutants revealed that $\mathrm{MTA}_{\mathrm{R} 315 \mathrm{~K}}$ replicates better than $\mathrm{MTA}_{\mathrm{P} 313 \mathrm{Q}}$ in the absence of KD-247. On the other hand, $\mathrm{MTA}_{\mathrm{P} 313 \mathrm{Q}}$ dominated over $\mathrm{MTA}_{\mathrm{R} 315 \mathrm{~K}}$ in the presence of KD-247.

\section{Conclusion}

The viral fitness to the cell and the resistance to the specific antibodies are major factors contributing the virus escape from neutralizing antibodies. Our results demonstrated the primary R5 isolate HIV-1 $1_{\mathrm{MTA}}$ underwent different escape pathway dependent on the concentration of the antibody. 